\title{
Effects of Parameters on Solvent Extraction of Oil From Sandbox (Hura Crepitans) Seed Oil Using $2^{4}$ Factorial Design
}

\author{
Owhor Sampson Chisa ${ }^{1}$, Amine J.D ${ }^{2}$, Abdul Gambo Alim ${ }^{3}$, Luka Bobby Shakarau ${ }^{3}$, \\ Isaiah Kehinde Ogbobame ${ }^{1}$, Samaila Yohanna Adidauki ${ }^{4}$ \\ ${ }^{1}$ Department of Pure and Applied Physics, Federal University Wukari, Taraba state, Nigeria \\ ${ }^{2}$ Department of Mechanical Engineering, University of Agriculture Makurdi, Benue State, Nigeria \\ ${ }^{3}$ Department of Food Science and Technology, Federal University Wukari, Taraba state, Nigeria \\ ${ }^{4}$ Department of Biological Sciences, Federal University Wukari, Taraba state, Nigeria
}

Received: February 20, 2021. Revised: April 2, 2021. Accepted: April 5, 2021. Published: April 13, 2021.

\begin{abstract}
The present work deals with the production of biodiesel from Sandbox (Hura crepitans) seed oil and the optimization of the parameters that influence the transesterification of Sandbox (Hura crepitans) seed oil into biodiesel using Response Surface Methodology. Hura crepitans oil was obtained from by using hydraulic press for Mechanical and n-hexane for solvent extraction. Esterification was done using methanol and sodium hydroxide. A total of 48 experiments using Central Composite Design were carried out. The R-Squared, Adequate Precision, Predicted and Adjusted R-Squared values were $0.9367,19.219,0.8576$ and 0.9070 respectively. The result of the extraction of oil, physiochemical properties, and optimization process shows that sandbox (Hura crepitans) seed oil has characteristics that are more favorable to biodiesel production. The optimal conditions for extraction of oil from sandbox seed oil were given as alcohol/ oil ratio of 5.0, catalyst amount of $20 \mathrm{~g} / \mathrm{ml}$, extraction temperature of $60^{\circ} \mathrm{C}$, and extraction time of 45.01 minutes, with the predicted oil yield as $97.33 \%$ respectively which shows that the experimental values are in good agreement with predicted values.
\end{abstract}

Keywords: Extraction, Factorial Design model, Oilseed, Optimization, Prediction

\section{INTRODUCTION}

An increase in demand for alternative for conventional fuel in the last three decades has led to an increasing demand for oilseed products and their byproducts. This has led to the need to search for more oilseeds, which can be use as raw materials for industrial purposes and which can launch a new path from prospective oil-producing seeds [1]. Ogunniyi [1] reported that in Africa, where most countries are struggling with development, there is a need to replace industrial oil to oil based seeds mostly used as food with non-edible ones. The replacement will be helpful in reducing the challenges of food competition as well as industrial uses of the same oil such as groundnut oil, moringa oil, soya oil, palm kernel oil, corn oil, and other edible oils [2]. Sandbox (Hura crepitans), also known as possum wood, and jabillo is an evergreen tree of the spurge family (Euphorbiaceae).

It is commonly planted in the cities and villages of the southwestern, north central (Ijesha in Osun State Markurdi in Benue and Kabba in Kogi), and southern (Edo State) parts of Nigeria, mostly as shade. Apart from being seen as a prospect for biodiesel production, sandbox may possibly have edible uses, industrial uses, and pharmaceutical uses [3]. Hura crepitans are fast growing and they can be grown and harvested on a continuous basis throughout the year under controlled cultural conditions. It appears to represent the recent renewable energy source of oil that could meet the global demand for fuels [4]. they have been extensively explored for their novel lipids and fatty acids [5]-[8].The reaction is affected by several parameters such as the concentration of catalyst, oil to methanol ratio, reaction temperature, moisture, presence of free fatty acids (FFA) and agitation intensity, etc. [9], [10].In this paper the statistical analysis of product yield was performed using Design Expert 8.0. Central Composite Design (CCD) was applied to optimize the catalyzed transesterification reaction variables. Optimization of parameters for biodiesel production from sandbox oil such as oil: alcohol ratio, catalyst amount, time and temperature are carried out. Regression analysis and analysis of variable was also made to test the significance of model. 


\section{MATERIALS AND METHODS}

\section{A. Materials}

Sandbox fruits, a natural precursor, were procured at Makurdi in Benue State, Nigeria.

The sandbox seed was dehusked, nuts were cracked with a small hammer and winnowed, oil seeds dried in the sun for two weeks for oil extraction.

$$
\begin{aligned}
& \text { Nut/Fruit ratio }=\frac{\text { Wt of Nut }}{\text { Wt of Fruit }} \ldots \ldots \ldots \ldots \ldots \ldots \ldots \ldots \ldots \ldots \ldots \ldots \ldots \\
& \text { Fruit } / \text { oil seed ratio }=\frac{\text { Wt of fruit }}{\text { Wt of Oil Seeds }} \ldots \ldots \ldots \ldots \ldots \ldots \\
& \text { Oil seed/ Nut ratio }=\frac{\text { Wt of oilseed }}{\text { Wt of nut }} \ldots \ldots \ldots \ldots \ldots \ldots \\
& \text { Oil } / \text { Oil seed ratio }=\frac{\text { Weight of oil from oil seeds }}{\text { weight of oil seeds }}
\end{aligned}
$$

\section{Factorial Experimental Design}

Researchers [9]-[11] have worked on Factorial design to determine the interaction of the dependent and independent variables.

This experiment was designed using Design Expert version 8.0, where a Box-Behnken experimental design was employed in order to optimize the

\section{B. Gravimetric analysis of oil seeds}

The average weight of dried sandbox fruit were determined using digital weighing instrument.

The following ratios were determined using equations below.

Table 1: Variation of parameters for $2^{4}$ factorial design

\begin{tabular}{llccccc}
\hline S/N & Name & $\begin{array}{c}\text { Lower } \\
\text { Limit }\end{array}$ & $\begin{array}{c}\text { Upper } \\
\text { Limit }\end{array}$ & $\begin{array}{c}\text { Lower } \\
\text { Weight }\end{array}$ & $\begin{array}{c}\text { Upper } \\
\text { Weight }\end{array}$ & Desirabilty \\
\hline 1 & Alcohol/oil ratio & $5: 1$ & $6: 1$ & 1 & 1 & 3 \\
2 & Catalyst amount & 10 & 20 & 1 & 1 & 3 \\
3 & Reaction Temperature & 50 & 60 & 1 & 1 & 3 \\
4 & Reaction Time & 45 & 60 & 1 & 1 & 5 \\
5 & Biodiesel yield & 75 & 98 & 1 & 1 & 5 \\
\hline
\end{tabular}

\section{Extraction of oil using solvent extraction}

The extraction of oil was carried out at the laboratory of the Department of Food Science and Technology, Federal University Wukari, Taraba State, Nigeria, using the method described by [9]. The extraction was done with a soxhlet apparatus of $250 \mathrm{~cm}^{3}$ capacity using $\mathrm{n}$-hexane of analytical grade as the solvent. The experimental runs were carried out according to the experimental runs generated Biodiesel yield (B.Y) $\%=\frac{V_{b}}{V_{S}} * 100 \ldots$

Where; B.Y= Biodiesel yield (\%)

$\mathrm{V}_{\mathrm{b}}=$ Volume of biodiesel recover $(\mathrm{g})$

$\mathrm{V}_{\mathrm{s}}=$ Volume of the oil used $(\mathrm{g})$

\section{E. Determination of Free Fatty Acid (FFA)}

Evaluation of some selected physicochemical properties of the sandbox oil was carried out using extraction of oil from sandbox kernels. $2^{4}$ factorial design of four (4) factors namely alcohol to oil ratio, catalyst amount, reaction temperature and reaction time was used giving rise to 48 experimental runs. The factors were varied at two levels; low and high level to determine the interactive factors for highest biodiesel yield. The summary of this is as shown in Table 1. from Design Expert as given in Table 3. The solvent used was recovered at every experimental run through a distillation process, and the actual oil obtained was weighed. The experiment was repeated for other parameters, and the percentage yield was calculated.

The oil yield for the extraction were determined by using the equation:

ASTMD 6751 standard procedures as described by [5]-[11]. Results is as shown in Table 4. 
F. Optimization studies using response surface methodology

Box-Behnken Design (BBD) methodology has been used to study the optimization of chemical processes and products [10]-[11]. A two level, four-factor Box-Behnken design (BBD) was employed using Design Expert 8.0. Software to examine the optimum conditions of extraction of oil from sandbox seed using solvent extraction. The generated runs for the BBD investigated in this work consist of 48 experimental runs. Validation experiments were conducted in the laboratory three times at the optimal conditions obtained from the optimization of biodiesel production from sandbox oil. The yield obtained from the validation experiment was compared with the optimum yield predicted.

\section{RESULTS AND DISCUSSION \\ A. Gravimetric Analysis of Seed Oil}

Table 2. Shows result obtained for gravimetric analysis of the sandbox oil seeds plants. The Average weight of dried fruit was $56.20 \mathrm{~g}$, Average weight of nut 33.09, Average weight of oil seeds 23.60, Average weight of oil (Mechanical) 5.80, Average weight of oil (solvent) 10.90, Nut / fruit ratio 0.59 , Fruit / oil seed ratio 2.38 , Oil seed / nut ratio 0.71 , Oil / oil seed ratio (mechanical extraction) 0.25 , Oil / oil seed ratio (solvent extraction) $0.46, \%$ oil produced (mechanical extraction) 25, \% oil produced (solvent extraction) 46.

Table 2: Gravimetric Analysis of Seed Oil

\begin{tabular}{ll}
\hline Items & Sandbox \\
\hline Average weight of dried fruit (g) & 56.20 \\
Average weight of nut (g) & 33.09 \\
Average weight of oil seeds (g) & 23.60 \\
Average weight of oil (Mechanical)(g) & 5.80 \\
Average weight of oil (solvent)(g) & 10.90 \\
Nut / fruit ratio & 0.59 \\
Fruit / oil seed ratio & 2.38 \\
Oil seed / nut ratio & 0.71 \\
Oil / oil seed ratio (mechanical extraction) & 0.25 \\
Oil / oil seed ratio (solvent extraction) & 0.46 \\
\% oil production (mechanical extraction) & 25.00 \\
$\%$ oil production (solvent extraction) & 46.00 \\
\hline
\end{tabular}

B. Result of oil yield from the extraction of oil from Sandbox

The result of the solvent extraction of oil from sandbox oil is presented in Table 3. The yield for each run of the experiment was determined using Equation 5. The varying oil yield values are indications that the extraction parameters considerably affect the oil yield. The maximum oil yield of $97 \%$ was obtained from the extraction of the corresponding Alcohol/oil ratio of 5.0, catalyst amount of $20 \mathrm{~g}$, reaction temperature of $60^{\circ} \mathrm{C}$, and extraction time of 45 minutes. The maximum value obtained for the yield seemed to be slightly high than $94.05 \%$ reported by Oniya [9] using solvent extraction and $n$-hexane as a solvent. It may be suggested that the variation in the oil yield of sandbox may be due to the differences in the variety of the fruit, the species, and the environmental conditions. This is an indication that the oil yield from the extraction of oil from sandbox kernels was affected by the process parameters or conditions. 
Table 3. Solvent extraction using $2^{4}$ factorial design and Percentage of oil yield

\begin{tabular}{|l|l|l|l|l|l|l|l|l|l|l|l|}
\hline RUNS & A & B & C & D & E & RUNS & A & B & C & D & E \\
\hline 1.00 & 6.00 & 10.00 & 50.00 & 60.00 & 80.00 & 25.00 & 5.00 & 10.00 & 50.00 & 45.00 & 93.00 \\
\hline 2.00 & 5.00 & 20.00 & 60.00 & 45.00 & 97.00 & 26.00 & 6.00 & 20.00 & 60.00 & 45.00 & 90.00 \\
\hline 3.00 & 5.00 & 10.00 & 50.00 & 60.00 & 87.00 & 27.00 & 5.00 & 20.00 & 60.00 & 60.00 & 79.00 \\
\hline 4.00 & 5.00 & 10.00 & 60.00 & 60.00 & 85.00 & 28.00 & 6.00 & 20.00 & 50.00 & 60.00 & 85.00 \\
\hline 5.00 & 6.00 & 20.00 & 50.00 & 45.00 & 84.00 & 29.00 & 5.00 & 10.00 & 50.00 & 60.00 & 83.00 \\
\hline 6.00 & 5.00 & 20.00 & 50.00 & 45.00 & 90.00 & 30.00 & 6.00 & 10.00 & 60.00 & 60.00 & 83.50 \\
\hline 7.00 & 6.00 & 10.00 & 50.00 & 60.00 & 88.00 & 31.00 & 6.00 & 20.00 & 60.00 & 60.00 & 81.00 \\
\hline 8.00 & 6.00 & 20.00 & 50.00 & 45.00 & 88.00 & 32.00 & 6.00 & 10.00 & 60.00 & 45.00 & 96.00 \\
\hline 9.00 & 5.00 & 20.00 & 60.00 & 45.00 & 96.00 & 33.00 & 6.00 & 20.00 & 50.00 & 60.00 & 85.00 \\
\hline 10.00 & 5.00 & 20.00 & 60.00 & 60.00 & 80.00 & 34.00 & 6.00 & 10.00 & 60.00 & 45.00 & 89.00 \\
\hline 11.00 & 6.00 & 10.00 & 60.00 & 60.00 & 83.00 & 35.00 & 5.00 & 10.00 & 60.00 & 60.00 & 83.00 \\
\hline 12.00 & 5.00 & 10.00 & 60.00 & 45.00 & 82.00 & 36.00 & 5.00 & 20.00 & 50.00 & 45.00 & 89.00 \\
\hline 13.00 & 6.00 & 10.00 & 60.00 & 45.00 & 89.00 & 37.00 & 5.00 & 20.00 & 60.00 & 60.00 & 78.00 \\
\hline 14.00 & 6.00 & 20.00 & 50.00 & 45.00 & 87.00 & 38.00 & 5.00 & 10.00 & 50.00 & 45.00 & 93.00 \\
\hline 15.00 & 6.00 & 10.00 & 50.00 & 45.00 & 92.00 & 39.00 & 6.00 & 20.00 & 50.00 & 60.00 & 84.50 \\
\hline 16.00 & 5.00 & 20.00 & 50.00 & 60.00 & 90.00 & 40.00 & 5.00 & 20.00 & 50.00 & 60.00 & 92.00 \\
\hline 17.00 & 6.00 & 10.00 & 60.00 & 60.00 & 82.00 & 41.00 & 5.00 & 20.00 & 50.00 & 60.00 & 91.00 \\
\hline 18.00 & 6.00 & 20.00 & 60.00 & 60.00 & 81.00 & 42.00 & 6.00 & 10.00 & 50.00 & 60.00 & 84.00 \\
\hline 19.00 & 6.00 & 20.00 & 60.00 & 60.00 & 82.00 & 43.00 & 5.00 & 20.00 & 50.00 & 45.00 & 89.70 \\
\hline 20.00 & 5.00 & 10.00 & 60.00 & 45.00 & 85.00 & 44.00 & 6.00 & 20.00 & 60.00 & 45.00 & 91.50 \\
\hline 21.00 & 5.00 & 10.00 & 50.00 & 45.00 & 94.00 & 45.00 & 6.00 & 20.00 & 60.00 & 45.00 & 91.00 \\
\hline 22.00 & 6.00 & 10.00 & 50.00 & 45.00 & 91.00 & 46.00 & 5.00 & 10.00 & 50.00 & 60.00 & 90.00 \\
\hline 23.00 & 5.00 & 10.00 & 60.00 & 45.00 & 82.50 & 47.00 & 5.00 & 10.00 & 60.00 & 60.00 & 83.00 \\
\hline 24.00 & 5.00 & 20.00 & 60.00 & 45.00 & 95.00 & 48.00 & 6.00 & 10.00 & 50.00 & 45.00 & 90.50 \\
\hline
\end{tabular}

C. Physicochemical Properties and Free Fatty Acid (FFA)

The result presented in Table 4 depicts the fuel properties of the biodiesel produced from sandbox using $\mathrm{KOH}$ as catalysts. Moisture content of $0.14 \%$, Density of $860 \mathrm{~kg} / \mathrm{m}^{3}$ was obtained with a specific gravity of 0.860 the result also shows appreciable consistency with the findings of [9]. Kinematics viscosity and Acid value $4.03 \mathrm{~mm}^{2} / \mathrm{s}$ and 0.31 $\mathrm{mg} / \mathrm{KOH}$ which is close to soybean and sunflower $4.12 \mathrm{~mm} / \mathrm{s}$ and $4.16 \mathrm{~mm}^{2} / \mathrm{s}$ respectively [6], [10]. Cloud point of $8.2^{\circ} \mathrm{C}$, Flash point of $197^{\circ} \mathrm{C}$, Pour point of $5.70^{\circ} \mathrm{C}$ and Cetane number of $62.12^{\circ} \mathrm{C}$ were found to be in close agreement with a previous work on the production of biodiesel from sandbox oil [7], [8]. Both flash point and pour point also falls within the bracket, this infer that the fuel is suitable for use in temperate regions with no challenges of gelling. The Cetane value was also found to fall above the minimum value, this indicates that the fuel will not present any challenge during ignition. The predominant Fatty acid was Oleic 56.50, Linoleic 17.90, Stearic 9.00, Palmitic 8.20. This values are in agreement with values from [5], [11]. 
Table 4: Properties of Sandbox methylester and Fatty acid Composition

\begin{tabular}{|c|c|c|c|c|c|c|}
\hline $\mathrm{S} / \mathrm{N}$ & Properties & $\begin{array}{c}\text { Sandbox } \\
\text { methylester }\end{array}$ & $\begin{array}{l}\text { ASTM } \\
\text { D6751 }\end{array}$ & EN 14214 & $\begin{array}{c}\text { Fatty acid } \\
\text { composition } \\
(\text { wt } \%)\end{array}$ & Sandbox \\
\hline 1 & Moisture content $\%$ & 0.14 & $\min 0.05$ & Min 0.02 & Lauric & 0.10 \\
\hline 2 & Specific gravity & 0.86 & $0.85-0.90$ & 0.85 & Myristic & 0.90 \\
\hline 3 & $\begin{array}{l}\text { Kinematic viscosity } \\
\left(\mathrm{mm}^{2} / \mathrm{s}\right) \text { at } 40{ }^{0} \mathrm{C}\end{array}$ & 4.03 & $1.9-6.0$ & $3.5-5.0$ & Palmitic & 8.20 \\
\hline 4 & $\begin{array}{c}\text { Acid value } \\
\text { (mg KOH/g oil) }\end{array}$ & 0.31 & $\min .0 .80$ & $\min 0.50$ & Stearic & 9.00 \\
\hline 5 & Cloud point ${ }^{0} \mathrm{C}$ & 8.20 & -15 to 5 & -3 to 12 & Oleic & 56.50 \\
\hline 6 & Flash point ${ }^{0} \mathrm{C}$ & 197 & $\begin{array}{c}\min 100- \\
170\end{array}$ & $\min 120$ & Linoleic & 17.90 \\
\hline 7 & Pour point ${ }^{0} \mathrm{C}$ & 5.70 & -35 to 15 & -15 to 16 & Linolenic & 4.10 \\
\hline 8 & Cetane number & 62.12 & $\min 47$ & $\min 51$ & Others & 3.30 \\
\hline
\end{tabular}

D. Optimization studies using response surface methodology

Determination of the optimum yield was based on numerical optimization using Design Expert software. These optimum conditions compared well with the experimental value, which gives the optimum oil yield of $97.00 \%$, a value slightly lower than the predicted value of $97.33 \%$. To verify and confirm the agreement between the results obtained from the model, the optimum conditions obtained were taken to the laboratory to validate the prediction of the model. A confirmatory experiment was done three times using the optimal conditions, and the average sandbox oil yield obtained was $95.64 \%$.

The validation experimental results are presented in Table 5. It was observed that the experimental values obtained were in good agreement with the values predicted from the models, with relatively small deviation between the predicted and actual values, which was $1.30,1.63$ and 2.13 respectively. According to Ali [3], the acceptable minimum error between the predicted and experimental data should be less than or equal to $10 \%$.

Table 5. Validation experiment at optimum condition for biodiesel production

\begin{tabular}{|l|l|l|l|l|l|l|l|}
\hline Runs & A & B & C & D & $\begin{array}{l}\text { Predicted yield, } \\
\text { \% }\end{array}$ & $\begin{array}{l}\text { Experimental } \\
\text { yield, \% }\end{array}$ & Difference \\
\hline $\mathbf{1}$ & 5.00 & 20.00 & 60.00 & 45.01 & 97.33 & 96.03 & 1.30 \\
\hline $\mathbf{2}$ & 5.00 & 20.00 & 60.00 & 45.01 & 97.33 & 95.70 & 1.63 \\
\hline $\mathbf{3}$ & 5.00 & 20.00 & 60.00 & 45.01 & 97.33 & 95.20 & 2.13 \\
\hline
\end{tabular}

A - Alcohol/oil; B- Catalyst amount; C- Extraction temperature; D- Extraction time

\section{E. Analysis of Variance (ANOVA)}

Analysis of variance (ANOVA) as shown in Table 6 designates the predictability of the model at $99 \%$ confidence level. In this case for sandbox, Alcohol/oil ratio (A), Extraction time (D), alcohol/oil and catalyst amount (AB), alcohol/oil and extraction temperature (AC), alcohol/oil and extraction time (AD), extraction temperature and extraction time (CD), Alcohol/oil-catalyst amount extraction temperature (ABC), Alcohol/oil-catalyst amount - extraction time (ABD), catalyst amount extraction temperature - extraction time (BCD), alcohol/oil -catalyst amount-reaction temperatureextraction time (ABCD) are significant model terms. The "Pred R-Squared" value of 0.8576 is a measure of how good the model predicted a response value."Adj R-Squared" of 0.9070 . The adjusted Rsquared basically plateaus when insignificant terms are added to the model, and the predicted R-squared 
will decrease when there are too many insignificant terms.

The multiple regression analysis of the experimental data gives a second-order factorial equation, which was modified to discard the insignificant $\mathrm{B}, \mathrm{C}, \mathrm{AD}$, $\mathrm{BC}, \mathrm{BD}, \mathrm{ABC}$, and $\mathrm{ACD}$ model terms. The reduced quadratic model developed depicts the interaction between the dependent oil yield (Y) and the coded values of the independent variables $A, D, A B, A C$, $\mathrm{CD}, \mathrm{ABD}, \mathrm{BCD}$ and $\mathrm{ABCD}$. This is shown in equation 6.

Coded Factors: $\mathrm{Y}=66.00-3.25 * \mathrm{~A}-4.21 * \mathrm{D}-$ $0.87 * \mathrm{~A} * \mathrm{~B}+1.21 * \mathrm{~A} * \mathrm{C}-9.04 * \mathrm{C} * \mathrm{D}+0.87 *$ $\mathrm{A} * \mathrm{~B} * \mathrm{D}-0.75 * \mathrm{~B} * \mathrm{C} * \mathrm{D}+1.33 * \mathrm{~A} * \mathrm{~B} * \mathrm{C} *$ D.

Table 6. Analysis of variance (ANOVA) for extraction of oil from sandbox

\begin{tabular}{|l|l|l|l|l|l|}
\hline Source & DF & Sum of Squares & Mean Square & F-Value & $\begin{array}{l}\text { p-value } \\
\text { Prob > F }\end{array}$ \\
\hline Model & 15 & 1292.77 & 86.18 & 31.57 & $<0.0001$ \\
\hline A & 1 & 2.61 & 2.61 & 0.96 & 0.3352 \\
\hline B & 1 & 2.00 & 2.00 & 0.73 & 0.3983 \\
\hline C & 1 & 30.40 & 30.40 & 11.14 & 0.0022 \\
\hline D & 1 & 554.88 & 554.88 & 203.25 & $<0.0001$ \\
\hline AB & 1 & 80.60 & 80.60 & 29.15 & $<0.0001$ \\
\hline AC & 1 & 114.70 & 114.70 & 42.01 & $<0.0001$ \\
\hline AD & 1 & 22.41 & 22.41 & 8.21 & 0.0073 \\
\hline BC & 1 & 2.43 & 2.43 & 0.89 & 0.3525 \\
\hline BD & 1 & 0.30 & 0.30 & 0.11 & 0.7421 \\
\hline CD & 1 & 132.67 & 132.67 & 48.60 & $<0.0001$ \\
\hline ABC & 1 & 25.23 & 25.23 & 9.24 & 0.0047 \\
\hline ABD & 1 & 75.50 & 75.50 & 27.66 & $<0.0001$ \\
\hline ACD & 1 & 3.10 & 3.10 & 1.14 & 0.2945 \\
\hline BCD & 1 & 129.36 & 129.36 & 47.39 & $<0.0001$ \\
\hline ABCD & 1 & 116.56 & 116.56 & 42.70 & $<0.0001$ \\
\hline Pure Error & 32 & 87.36 & 2.73 & & \\
\hline Cor Total & 47 & 1380.13 & & & \\
\hline R-Squared & 0.9367 & & & \\
\hline Adeq Precision & 19.219 & & \\
\hline Pred R-Squared & 0.8576 & & \\
\hline Adj R-Squared & 0.9070 & C-Extraction temperature & D- Extraction time \\
\hline A-Alcohol/oil & B-Catalyst amount & & \\
\hline
\end{tabular}

$F$. Effect of the alcohol/oil ratio and catalyst amount on the oil yield from sandbox

The 3D surface plot interaction from Design Expert represents the effects of alcohol/oil ratio and catalyst amount. Their reciprocal interactions on the oil yield for extraction were studied. It was observed that increase in alcohol/oil ratio favors the extraction rate as much solvent is needed for extraction, while the oil yield increases gradually as catalyst amount increases until the boiling temperature of the solvent is reached, when the yield starts declining. The curvature nature of the surface plot in Figure 1 depicts a mutual interaction between catalyst amount and alcohol/oil ratio.

G. Effect of alcohol/oil ratio and extraction temperature on the oil yield

The effect of alcohol/oil ratio and extraction temperature was studied using the 3D surface plot in Figure 2, which depicts the interaction between alcohol/oil ratio and extraction temperature.

The higher the temperature, the higher the extraction rate, until the temperature rises above the boiling temperature of the solvent, when further increment of the temperature led to a decrease in the oil yield. 
It can be deduced from the analysis of variance (ANOVA) results that the combined effects of alcohol/oil ratio and extraction temperature have a significant effect on the oil yield

\section{$H$. Effect of extraction time and extraction temperature on} the oil yield

From Figure 3, the elliptical nature of the contour plots indicated that interaction between the extraction temperature and time had a direct significant effect on the yield of oil. It was noticed that increase in time favored the extraction of oil until it got close to the moderate reaction time.
Increased reaction time above this level tends to produce lower oil yields. The oil yield was observed to decrease with higher temperature particular at the temperature higher than the boiling point of the solvent. This is because at this temperature higher than the boiling temperature of the solvent, evaporation of the solvent will take place as a result of the increased temperature. The combined effect of these two reaction variables at high-level experimental process will obviously result in a decrease in oil yiel d.

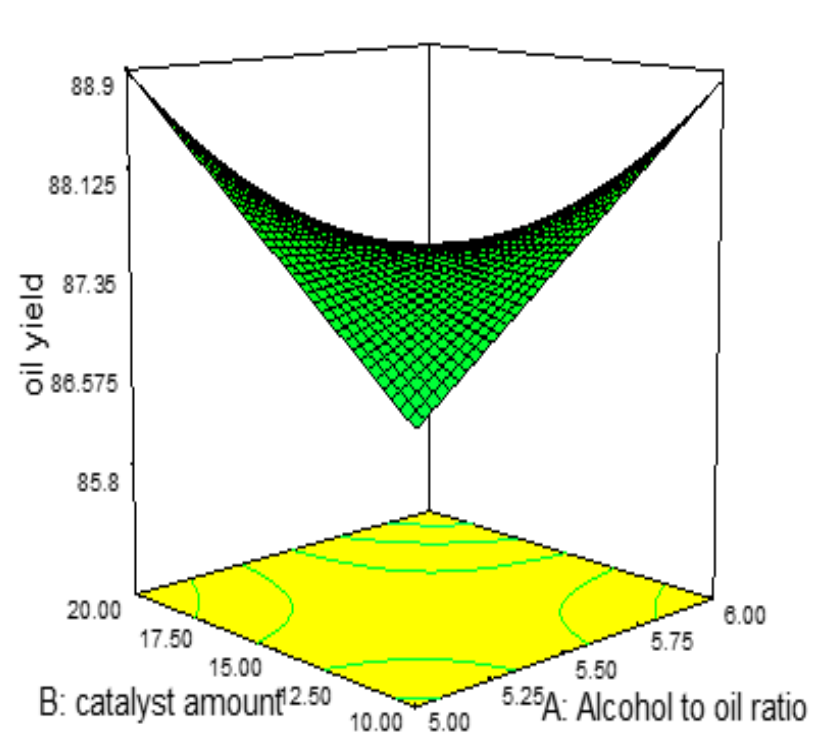

Figure 1

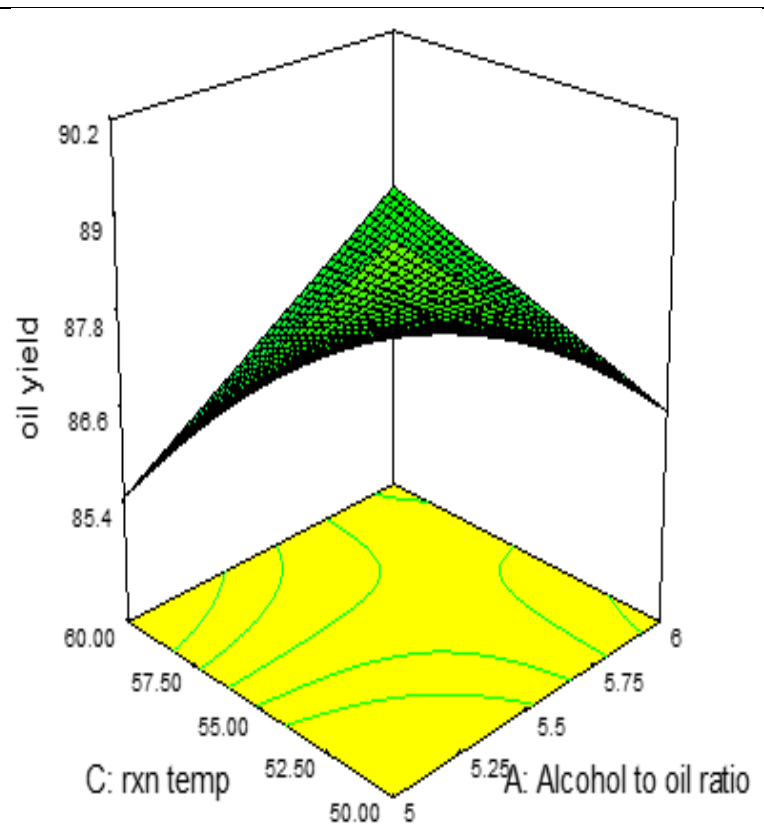

Figure 2

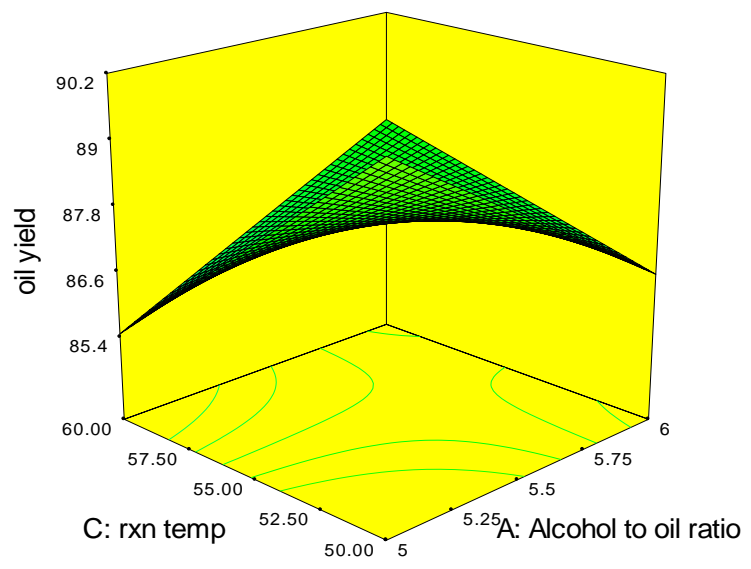

Figure 3. 


\section{CONCLUSION}

Based on the findings of this research work (the result of the extraction of oil, physiochemical properties, and optimization process), sandbox (Hura crepitans) seed oil has characteristics that are more favorable to biodiesel production. Extraction of oil can be done using both mechanical and solvent methods. The optimal conditions for extraction of oil from sandbox were given as alcohol/ oil ratio of 5.0, catalyst amount of $20 \mathrm{~g} / \mathrm{ml}$, extraction temperature of $60{ }^{\circ} \mathrm{C}$, and extraction time of 45.01 minutes, with the predicted oil yield as $97.33 \%$.

\section{REFERENCES}

[1] D.S. Ogunniyi, "Castor Oil: A Vital Industrial Raw Material". Bioresource Tech., pp: 1086-1091, 2005.

[2] S.O. Giwa, L.A. Chuah, and N.M. Adam, "Investigating Egusi (Citrullus Colocynthis L.) Seed oil as potential biodiesel feedstock", Energies, vol. 3, pp: 607-18, 2010.

[3] Y. Ali, and M.A. Hanna, "Physical Properties of Tallow Ester and Diesel Fuel Blends", Bioresource Technol. Vol. 47, pp: 31-40, 2010.

[4] J.D. Amine, S.C. Owhor, and B.S. Luka, "Engine Performance Characteristics of Biodiesel from Oils of Sandbox Seed and Moring as Feedstock" Journal of Multidisciplinary Engineering Science and Technology (JMEST), ISSN: 24589403 Vol. 5 Issue 12, December 2018.

[5] A. Gopinath, and N.G. Sukumar Puhan, "Relating cetane number of biodiesel fuels to their fatty acid composition: a critical study", Proc Inst Mech Eng. pp: 565-583, 2009.

[6] P.N. Okolie, E. Uaboi, and A.E. Ajekwene, "Extraction and Quality Evaluation of Sandbox Tree Seed (Hura crepitan) Oil" World Journal of Agricult. Sci., vol. 8, pp: 359-365, 2012.

[7] K .A. Alabi, "Analysis of Fatty Acid Composition of Thevetia peruviana and Hura crepitans Seed Oils Using GC-FCID”, Fountain Journal of Natural and Applied Sciences, vol. 2, pp: 32-37, 2013.

[8] A. Adewuyi, P.O. Awolade, and R.A. Oderinde, "Hura crepitans Seed Oil: An Alternative Feedstock for Biodiesel", Production Journal of Fuel, vol. 97, pp: 1086-1091, 2014.
[9] O.O. Oniya, F.B. Akande, A.A. Adedeji, and O.L. Olukayode, "Transesterification of Hura crepitans oil for biodiesel production", Journal of Engineering, Appl. Scientific Res. Vol. 16, pp:9197, 2014.

[10] C.V.D. Ven, H. Gruppen, D.B.A.D. Bont, and A.G.J. Vorga, "Optimization of Angiotensin Converting Enzyme Inhibit by Whey Protein Hydrolysis Using Response Surface Methodology", Journal of International Dairy, Vol. 12, pp: 817-820, 2002

[11] C. Mane, M. Souquet, D. Olle, C. Verries, F. Veran, G. Mazeromech, V. Chenynier, and H. Fukraud, "Optimization of Simultaneous Flavanol, Phenolic Acid and Anthocyanin Extraction from Grapes Using and Experimental Design: Application to the Characterisation of Champagne Grapes Varieties". Journal of Agriculture, Food Chemistry Vol. 55, pp: 7224-7233, 2007.

\section{Creative Commons Attribution License 4.0 (Attribution 4.0 International, CC BY 4.0)}

This article is published under the terms of the Creative Commons Attribution License 4.0 https://creativecommons.org/licenses/by/4.0/deed.en_US 